\title{
Detection of multiple presence of antibiotic residues in slaughtered sheep at Duhok abattoir, Iraq
}

\author{
Sh.A. Yousif ${ }^{1}$ and Dh.M. Jwher ${ }^{2} \mathbb{D}$ \\ ${ }^{1}$ Veterinary Director, Duhok, ${ }^{2}$ Department of Veterinary Public Health, College of Veterinary Medicine, University of \\ Mosul, Mosul, Iraq
}

\begin{tabular}{l} 
Article information \\
\hline Article history: \\
Received November 5, 2019 \\
Accepted December 31, 2019 \\
Available online September 7, 2020 \\
\hline Keywords: \\
Antibiotic residues \\
ELISA \\
Sheep carcasses \\
Duhok abattoir \\
\hline Correspondence: \\
Dh.M. Jwher \\
deea gmx.us
\end{tabular}

$\mathrm{mx.us}$

DOI: 10.33899/ijvs.2019.126259.1276, @2021, College of Veterinary Medicine, University of Mosul.

This is an open access article under the CC BY 4.0 license (http://creativecommons.org/licenses/by/4.0/).

\section{Introduction}

Meat is an esteemed article of human diet as it provides proteins, energy, minerals and most B complex vitamins (1). Animal food industries are rapidly growing with consequent demand of healthy wholesome animal (2). In spite of their merits, meat could be a source of health hazards if it contains harmful material such as pathogens, toxins, residues of chemical agents as a parent compound or its metabolites (3). Residues in meat may result from many sources such as pesticides or from veterinary drugs which used to prevent or treat diseases, or to promote growth (4). Other disadvantages are that withdrawal time in relation to the maximum residue limit (MRL) is not taken into account (5-8). Nowadays, antibiotics play a major role to rise agriculture and to enhance feed conversion in livestock industries (2). The most commonly used antimicrobials in food producing animals are the $\beta$-Lactames, aminoglycosides, macrolides, sulfonamides and lincosamides (3). Public health hazards associated with these residues include direct toxic effects on consumers like allergic reactions and indirect problems through induction of resistant strains of pathogenic bacteria (9). Residues from these antibiotics may be present in edible tissues, milk and eggs and may exert different levels of toxicity on consumers when consuming them (2). Thus, easy, rapid and sensitive tests are really needed for an effective at line use (10). At present, there are various ways for detection of antibiotic residues which include microbiological, instrumental and immunoassay methods (11). A great proportion of livestock in Duhok province is reared by the herdsmen who administer animal pharmaceutical agents particularly incorrect dosage of antibiotics without veterinary prescription and with ignorance of withdrawal periods $(12,13)$.

The aims of this study is to detect and determine the residues of single or multiple presence of tetracycline, penicillin G, streptomycin and gentamicin in meat and various edible tissues of sheep slaughtered at Duhok province, Iraq. 


\section{Materials and methods}

\section{Sampling}

Eighty-eight samples have been collected from 22 sheep carcasses which were slaughtered within one week of August 2013 in Duhok abattoir to analyze for antibiotic residue by ELISA test. The samples were intentionally collected from organs and tissues suffering and affected by different pathological lesions. Four samples of $200 \mathrm{gm}$ of Longissimus dorsi, diaphragmatic muscle, liver and kidney were taken and packed in clean plastic bags. Samples of the current study were intentionally taken from certain clinical cases and those suffering from pathological changes. The identified samples were transported immediately to the Faculty of Veterinary Medicine, Public Health laboratory, Duhok University in an ice box with a minimum period of delay. The samples were stored at $-20^{\circ} \mathrm{C}$ in the freezer.

\section{Sample preparation}

Samples were finely homogenized to create a uniform form and were then extracted for each investigated antibiotic i.e. tetracycline, penicillin $\mathrm{G}$, streptomycin and gentamicin according to the protocol recommended by the kit supplier (Shenzhen Lvshiyuan Biotechnology Co., Ltd, China). ELISA kits stored at $4^{\circ} \mathrm{C}$. The product codes are LSY-10006, LSY-10019, LSY- 100024-2 and LSY-10023 for tetracycline, penicillin g, streptomycin and gentamicin, respectively.

\section{Calculation of antibiotics concentrations}

The concentrations of antibiotics in the samples were calculated according to the following formula, Percentage of absorbance value $=\mathrm{B} / \mathrm{B}_{0} * 100$. In which $\mathrm{B}$ is the optical density value of samples and $B_{0}$ is the optical density value of the standard solution. The values were then multiplying by the dilution factor as suggested by the kit manual. The standard and test absorbencies were entering manually to IPC software-version 4 from IPC Company, which then interpreted test results. Then the values were compare with the Maximum residue level (MRL) according EU standards (14).

Table 1: MRL of different organs according EU standards (ppb)

\begin{tabular}{lccc}
\hline Type of antibiotic & Muscles & Liver & Kidney \\
\hline Tetracycline & 100 & 300 & 600 \\
Penicillin G & 50 & 50 & 50 \\
Streptomycin & 500 & 500 & 1000 \\
Gentamicin & 50 & 200 & 750 \\
\hline
\end{tabular}

\section{Results}

The results of ELISA test for the examined samples of Longissimus dorsi muscle showed that there were different concentrations of antibiotics residues at a rate $(\mathrm{ppb})$ of $138.4522,355.6462,227.1922$ and 897.0317 with a percentage of $40.9 \%, 40.9 \%, 45.45 \%$ and $13.63 \%$ for tetracycline, penicillin, streptomycin and gentamicin, respectively (Table 2 and 3 ).

The results referred that there were different concentrations of antibiotics residues of diaphragmatic muscle samples at a rate ppb of 72.868, 397.5671, 465.6912 and 428.12 with a percentage of 59.09, 50, 50 and $22,72 \%$ for tetracycline, penicillin, streptomycin and gentamicin, respectively (Table 4 and 6).

The findings also indicated different concentrations of liver samples, where recorded at a rate ppb of 108.6313 , $593.4464,343.4162$ and 839.074 in a percentage of 54.54, $22.72,27.27$ and $13.63 \%$ for tetracycline, penicillin, streptomycin and gentamicin respectively (Table 5 and 7).

The results also showed that there were different concentrations of kidney samples at a rate of 72.868 , $397.5671,465.6912$ and 428.12 with a percentage of $59.09 \%, 50 \%, 50 \%$ and $22,72 \%$ for tetracycline, penicillin, streptomycin and gentamicin respectively (Table 8 and 10). The table revealed co- and multiple presence of more than one antibiotic residue in sheep carcasses as shown in table 9.

Table 2: Antibiotics residues levels (ppb) levels in Longissimus dorsi muscle by using ELISA technique

\begin{tabular}{ccccc}
\hline \multicolumn{5}{c}{ Carcass } \\
No. & Longissimus dorsi muscle antibiotic residues (ppb) \\
\cline { 2 - 5 } & Tetracycline & Penicillin G & Streptomycin & Gentamicin \\
\hline 1 & & & 5.005 & $926.133^{*}$ \\
3 & 29.641 & & & \\
4 & & $721.621^{*}$ & 34.351 & \\
5 & & $298.001^{*}$ & 159.993 & \\
6 & & $288.952^{*}$ & 82.183 & \\
7 & $145.348^{*}$ & & & $847.038^{*}$ \\
8 & & $469.330^{*}$ & 3.672 & \\
9 & & & & \\
10 & $114.266^{*}$ & & & \\
11 & $175.192^{*}$ & & & \\
12 & & $645.102 *$ & $690.307^{*}$ & \\
13 & & 23.843 & $690.307^{*}$ & \\
14 & & & & $917.924^{*}$ \\
15 & $254.109^{*}$ & & & \\
16 & & & & \\
17 & & & & \\
18 & $195.051^{*}$ & $252.473^{*}$ & 22.183 & \\
19 & $189.181^{*}$ & $482.366^{*}$ & $580.249^{*}$ & \\
20 & $111.018^{*}$ & & & \\
21 & 32.264 & 19.128 & 3.672 & \\
22 & & & & \\
$*$ Over the MRL according EU standards. &
\end{tabular}


Table 3: Mean and range of antibiotics residues levels and their positivity in Longissimus dorsi muscle by using ELISA technique

\begin{tabular}{lcccc}
\hline Samples & No. of Positive samples & Range of Str. conc. ppb & Mean (ppb) & Positive (\%) \\
\hline Tetracycline residues level $(\mathrm{ppb})$ & 9 & $29.641-254.109$ & 138.4522 & 40.9 \\
Penicillin G residues level $(\mathrm{ppb})$ & 9 & $19.128-645.102$ & 355.6462 & 40.9 \\
Streptomycin residues level $(\mathrm{ppb})$ & 10 & $3.672-690.307$ & 227.1922 & 45.45 \\
Gentamicin residues level $(\mathrm{ppb})$ & 3 & $847.038-926.133$ & 897.0317 & 13.63 \\
\hline
\end{tabular}

Table 4: Antibiotics residues levels (ppb) levels in diaphragmatic muscle by using ELISA technique

\begin{tabular}{ccccc}
\hline Carcass & \multicolumn{4}{c}{ diaphragmatic muscle antibiotic residues (ppb) } \\
\cline { 2 - 5 } No. & Tetracycline & Penicillin G & Streptomycin & Gentamicin \\
\hline 1 & & 33.325 & 39.962 & $922.825^{*}$ \\
2 & 8.668 & & & \\
3 & & $579.859^{*}$ & $680.306^{*}$ & \\
4 & 16.923 & $601.547^{*}$ & $581.030^{*}$ & \\
5 & 9.857 & $274.853^{*}$ & $581.030^{*}$ & \\
6 & & & & 36.032 \\
7 & 79.361 & & & \\
8 & $168.328^{*}$ & $479.718^{*}$ & $584.667^{*}$ & \\
9 & & & & \\
10 & $122.931^{*}$ & & 149.656 & \\
11 & 58.107 & & & \\
12 & & $768.773^{*}$ & & \\
13 & 66.443 & & & $368.421^{*}$ \\
14 & & & & \\
15 & $176.845^{*}$ & & & \\
16 & & $552.940^{*}$ & $690.306^{*}$ & $572.305^{*}$ \\
17 & $100.505^{*}$ & & & \\
18 & & $702.189^{*}$ & $580.214^{*}$ & $241.017^{*}$ \\
19 & 13.007 & $86.964^{*}$ & $672.113^{*}$ & \\
20 & 68.207 & $242.010^{*}$ & 486.288 & \\
21 & 58.107 & & & \\
22 & & $51.06^{*}$ & 77.031 & \\
\hline
\end{tabular}

* Over the MRL according EU standards.
Table 5: Antibiotics residues levels (ppb) levels in in local sheep carcasses in liver by using ELISA technique

\begin{tabular}{ccccc}
\hline Carcass & \multicolumn{4}{c}{ Liver antibiotic residues (ppb) } \\
\cline { 2 - 5 } No. & Tetracycline & Penicillin G & Streptomycin & Gentamicin \\
\hline 1 & & & & $914.245^{*}$ \\
2 & 129.841 & & & \\
3 & & $647.441^{*}$ & 35.601 & \\
4 & & & & \\
5 & 105.354 & $590.589^{*}$ & 65.801 & \\
6 & & & & $628.772^{*}$ \\
7 & 150.033 & & & \\
8 & 124.766 & $399.862^{*}$ & $584.667^{*}$ & \\
9 & & & & $974.205^{*}$ \\
10 & 111.266 & & & \\
11 & 137.995 & $667.147^{*}$ & $680.206^{*}$ & \\
12 & & $662.193^{*}$ & $690.211^{*}$ & \\
13 & 77.235 & & & \\
14 & & & & \\
15 & 224.150 & & & \\
16 & & & & \\
17 & 35.982 & & & \\
18 & 105.854 & & & \\
19 & 88.233 & & & \\
20 & 12.866 & & & \\
21 & & & & \\
22 & & & & \\
\hline
\end{tabular}

* Over the MRL according EU standards.

Table 6: Mean and range of antibiotics residues levels and their positivity in diaphragmatic muscle by using ELISA technique

\begin{tabular}{lcccc}
\hline Samples & No. of Positive samples & Range of Str. conc. ppb & Mean $(\mathrm{ppb})$ & Positive (\%) \\
\hline Tetracycline residues level $(\mathrm{ppb})$ & 13 & $8.668-176.845$ & 72.868 & 59.09 \\
Penicillin G residues level $(\mathrm{ppb})$ & 11 & $33.325-768.773$ & 397.5671 & 50 \\
Streptomycin residues level $(\mathrm{ppb})$ & 11 & $39.962-690.306$ & 465.6912 & 50 \\
Gentamicin residues level $(\mathrm{ppb})$ & 5 & $36.032-922.825$ & 428.12 & 22.72 \\
\hline
\end{tabular}

Table 7: Mean and range of antibiotics residues levels in in liver by using ELISA technique

\begin{tabular}{lcccc}
\hline Samples & No. of Positive samples & Range of Str. conc. ppb & Mean (ppb) & Positive (\%) \\
\hline Tetracycline residues level (ppb) & 12 & $12.866-150.033$ & 108.6313 & 54.54 \\
Penicillin G residues level (ppb) & 5 & $399.862-667.147$ & 593.4464 & 22.72 \\
Streptomycin residues level (ppb) & 6 & $4.011-690.211$ & 343.4162 & 27.27 \\
Gentamicin residues level (ppb) & 3 & $628.772-974.205$ & 839.074 & 13.63 \\
\hline
\end{tabular}


Table 8: Antibiotics residues levels in local sheep carcasses in kidney by using ELISA technique

\begin{tabular}{ccccc}
\hline Carcass & \multicolumn{4}{c}{ Kidney antibiotic residues (ppb) } \\
\cline { 2 - 5 } No. & Tetracycline & Penicillin G & Streptomycin & Gentamicin \\
\hline 1 & & & 19.885 & 346.863 \\
2 & 120.539 & $280.113^{*}$ & 581.030 & \\
3 & & $499.352^{*}$ & 489.901 & \\
4 & 112.627 & 674.609 & 433.871 & \\
5 & 116.497 & $320.452^{*}$ & 581.030 & \\
6 & & & & $975.660^{*}$ \\
7 & 166.443 & & & \\
8 & 169.282 & $341.238^{*}$ & 143.600 & \\
9 & & & & 721.961 \\
10 & 58.107 & & & \\
11 & 85.428 & $515.873^{*}$ & 70.870 & \\
12 & & $138.365^{*}$ & 682.401 & $913.308^{*}$ \\
13 & 9.961 & & & \\
14 & & & & $943.407^{*}$ \\
15 & 215.934 & 34.108 & 671.578 & \\
16 & & $464.780^{*}$ & 689.421 & \\
17 & 6.357 & & & \\
18 & 75.442 & $241.352^{*}$ & 580.331 & \\
19 & 82.337 & & & \\
20 & 75.791 & $130.085^{*}$ & 496.288 & \\
21 & & & & 213.510 \\
22 & & & & \\
\hline
\end{tabular}

* Over the MRL according EU standards.
Table 9: Multi-presence of antibiotic residues in local sheep carcasses

\begin{tabular}{ccccc}
\hline $\begin{array}{c}\text { Carcass } \\
\text { No. }\end{array}$ & Tetracycline & Penicillin G & Streptomycin & Gentamicin \\
\hline 1 & & $\mathrm{x}$ & $\mathrm{x}$ & $\mathrm{x}$ \\
2 & $\mathrm{x}$ & $\mathrm{x}$ & $\mathrm{x}$ & \\
3 & & $\mathrm{x}$ & $\mathrm{x}$ & \\
4 & $\mathrm{x}$ & $\mathrm{x}$ & $\mathrm{x}$ & \\
5 & $\mathrm{x}$ & $\mathrm{x}$ & $\mathrm{x}$ & \\
6 & & & & $\mathrm{x}$ \\
7 & $\mathrm{x}$ & & & \\
8 & $\mathrm{x}$ & $\mathrm{x}$ & $\mathrm{x}$ & \\
9 & & & & $\mathrm{x}$ \\
10 & $\mathrm{x}$ & & & \\
11 & $\mathrm{x}$ & $\mathrm{x}$ & $\mathrm{x}$ & \\
12 & & $\mathrm{x}$ & $\mathrm{x}$ & $\mathrm{x}$ \\
13 & $\mathrm{x}$ & $\mathrm{x}$ & $\mathrm{x}$ & \\
14 & & & & $\mathrm{x}$ \\
15 & $\mathrm{x}$ & $\mathrm{x}$ & $\mathrm{x}$ & \\
16 & & $\mathrm{x}$ & $\mathrm{x}$ & \\
17 & $\mathrm{x}$ & & & $\mathrm{x}$ \\
18 & $\mathrm{x}$ & $\mathrm{x}$ & $\mathrm{x}$ & $\mathrm{x}$ \\
19 & $\mathrm{x}$ & $\mathrm{x}$ & $\mathrm{x}$ & \\
20 & $\mathrm{x}$ & $\mathrm{x}$ & $\mathrm{x}$ & \\
21 & $\mathrm{x}$ & $\mathrm{x}$ & $\mathrm{x}$ & \\
22 & & $\mathrm{x}$ & $\mathrm{x}$ & $\mathrm{x}$ \\
\hline$\%$ & 63.64 & 72.73 & 72.73 & 36.37 \\
\hline
\end{tabular}

$\mathrm{X}$ refers to the presence of the residues.

Table 10: Mean and range of antibiotics residues levels (ppb) in kidney by using ELISA technique

\begin{tabular}{lcccc}
\hline Samples & No. of Positive samples & Range of Str. conc. ppb & Mean $(\mathrm{ppb})$ & Positive (\%) \\
\hline Tetracycline residues level $(\mathrm{ppb})$ & 13 & $6.357-215.934$ & 103.3288 & 59.09 \\
Penicillin G residues level $(\mathrm{ppb})$ & 11 & $34.108-674.609$ & 351.0242 & 50 \\
Streptomycin residues level $(\mathrm{ppb})$ & 12 & $19.885-689.421$ & 449.4471 & 54.54 \\
Gentamicin residues level $(\mathrm{ppb})$ & 6 & $213.510-975.660$ & 780.2398 & 27.27 \\
\hline
\end{tabular}

\section{Discussion}

In Iraq, the classic habit followed in which animal breeders administer a wide spectrum of veterinary drugs randomly to their animals without observing the withdrawal periods of these drugs before they are slaughtered for human consumption. Table 2 and 3 showed the percentage of samples containing tetracycline residues which referred that $50 \%$ of positive samples of Longissimus dorsi and diaphragm muscle exceeded recommended MRL $100 \mathrm{ppb}$ as per EU standards for muscles (14).

Meat is considered as an essential feedstuff for human beings due to its high nutritional value, digestibility and palatability (1). In Iraq, livestock including sheep represent the main source of animal protein. Consequently, the emergent and increasing demand for animal products oblige many animal raisers to expand their scale of livestock production and to increase their profitable business by using different antibiotics indiscriminately and application of "Blanket treatment" for such animals without observing and attention of withdrawal periods of drugs to clinically diseased or apparently healthy sheep before being slaughtered $(15,16)$.

Residual tetracycline levels of liver and kidney samples were below the maximum residual limit $300 \mathrm{ppb}$ for liver and $600 \mathrm{ppb}$ for kidney according to EU standards for both organs (14).

However, these values were not exceeding the MRL (14), suggesting that such animals had been treated with the drug and probably were not allowed adequate withdrawal period.

Tables 4-8 showed the percentage of Longissimus dorsi, liver, kidney diaphragmatic muscle samples containing penicillin $\mathrm{G}$ residues. The table also showed that $85 \%$ of positive samples of Longissimus dorsi and diaphragm 
contained which where over the MRL $50 \mathrm{ppb}$ as per EU standards for all the examined organs (14).

Tables 2-7 showed the percentage of Longissimus dorsi, diaphragmtic muscle, liver and kidney samples containing streptomycin residues referring that $47.6 \%$ of positive for the first two organs which contained residues levels over the MRL $500 \mathrm{ppb}$ for liver and below the MRL $1000 \mathrm{ppb}$ for kidney according to EU standard (14).

Regarding the percentage of gentamicin residues in different tissues, table 8 and 10 showed that $87.5 \%$ of both Longissimus dorsi and diaphragmatic muscles had residues over the MRL $50 \mathrm{ppb}$ according to EU standard for muscles (14). On the other hand, these residues where $100 \%$ and $50 \%$ in the samples of liver and kidney, respectively according to the aforementioned standard (14).

It was found that, penicillin $\mathrm{G}$ and streptomycin $72.73 \%$ were present in a large number of the carcasses followed by tetracycline $63.64 \%$ and gentamicin $36.37 \%$, which could be accounted to the availability of these antibiotics in local markets with low cost promoted their broad administration. It should be noted that penicillin $G$ and streptomycin is dispersed in one combination solution called PS. Such occurrences of multiple residues in the inspected meats may be attributed to the fact that these samples were intentionally collected from animals suffered from several diseases reflected and manifested subsequently by abnormal and pathological lesions in their carcasses.

The lower percentage of gentamicin residue obtained is due to the fact that this drug has limited uses, since it is only used for urogenital infections which were actually found in the examined carcasses fulfilling those goals of the study.

In Iraq, there are limited numbers of studies on the detection of antibiotics in food of animal origin, (17) found that $52 \%$ of poultry meat samples were positive for various antibiotic residues. Subsequently, (11) reported the streptomycin residue rate as $50 \%$ and $60 \%$ in ovine and bovine meat samples, respectively. $(18,19)$ found detectable levels of antibiotics in milk samples collected from Afak city, Al-Diwaniya and Mosul Province- Iraq, respectively. Multiple antibiotic residues $18 \%$ were found by (20) in meat from slaughtered cattle in Nigeria. However, a high percentage of antibiotic residues were found by (21) in Egypt, 58\% of kidney samples and 14\% of muscle in cattle samples were positive, while the percentage in buffaloes was $40 \%$ and $20 \%$, for kidney and muscles, respectively. The lower percentage $2 \%$ of oxytetracycline residues was obtained by (22) in bovine carcasses slaughtered at Mansoura Abattoir, Egypt.

Our findings were in agreement with those of (23) from Thailand, who found that out of 130 samples, 51 (39\%) were positive for at least one of the tested antibiotic. Several authors from different developing countries detected higher proportion of antibiotic residues in various animal producing food (24-27). A similar study carried out by (28) in Iran, showed that $14 \%$ of mutton and $22.8 \%$ of beef samples contained antibiotic residues. In Turkey, a study done by (29) revealed that $57.7 \%$ of beef samples and $45.7 \%$ of chicken meat samples collected from Ankara markets were positive for antibiotic residues. Similarly, (30) from Nigeria found that $46 \%$ of samples were positive to residues of tetracyclines. A study performed by (31) in Algeria, showed a strong presence of antibiotic residues in poultry meat, with $85.5 \%$ positive samples, most of them contained penicillin, tetracycline and aminoglycosides.

Generally, it is obvious that high rates of residues in various animal tissues and products are reported in developing countries in contrast to what is found in the developed world according to the European Community findings. Such reports revealed that positive samples for antibiotic residues in food of animal origin were less than $1 \%$, exactly $0.19 \%$ (32), which could be attributed to the type of animal husbandry, management and production system.

\section{Conclusion}

Consequently, in developing countries a greater proportion of animal breeding is done by uncultivated herdsmen who always purchase veterinary drugs over the counter for administration to their animals without a veterinary diagnosis, prescription and supervision, and it may still be regarded as a health hazards as they may cause allergic reactions or produce drug-tolerant bacteria. Unfortunately, this condition is an indication of lack of public health regulatory control in developing countries, which require urgent care and attention.

\section{Acknowledgments}

On behalf of the researchers, I extend my thanks and gratitude to the College of Veterinary Medicine, University of Mosul, for its continuous support for the research work

\section{Conflict of Interest}

The corresponding author (on behalf of all co-authors) should submit a conflict of interest disclosure form and is responsible for the accuracy and completeness of the submitted manuscript. Conflict of Interest Disclosure form can be signed by the corresponding author on behalf of all co- authors and stating that the submitted manuscript is the authors' original work, has not received prior publication and is not under consideration for publication elsewhere, permission has been received to use any material in the manuscript much as tables, figures etc. or no permissions have necessary to publish the authors' work. 


\section{References}

1. Bender A. Meat and meat products in human nutrition in developing countries. Rome: FAO Press Office; 1992. 6-74 p. Doi: 10.3/ T0562E/T0562E00

2. Sarmah AK, Meyer MT, Boxall ABA. A global perspective on the use, sales, exposure pathways, occurrence, fate and effects of veterinary antibiotics (VAs) in the environment. Chemosphere. 2006;65(5):72559. Doi: 10.1016/j.chemosphere.2006.03.026

3. Lee MH, Lee HJ, Ryu PD. Public health risks: Chemical and antibiotic residues, korea. Asian-Australasian J Anim Sci. 2001;14(3):402-13. Doi: 10.5713/ajas.2001.402

4. Mahgoub O, Kadim IT, Ann SA, Annamalai K. Use of enzyme linked immuno-sorbent assay (ELISA) for detection of antibiotic and anabolic residues in goat and sheep meat. World J Agric Sci. 2006;2(3):298-302.

5. Passantino A, Russo C. Maximum residue levels of veterinary medicines in relation to food safety: european community legislation and ethical aspects. J für Ver Leb. 2008;3(4):351-8. Doi: 10.1007/s00003-008-0369-x

6. WHO/FAO. Evaluation of certain veterinary drug residue in food. Seventieth report of the Joint FAO/WHO Expert Committee on Food Additives. New York: WHO Technical Report Series; 2009. 954 p.

7. Wachira MW. Evaluation of the performance of Bacillus cereus and Bacillus subtilis as test organisms for assay of tetracyclines and beta lactams in chicken meat [Master's thesis]. Kenia: Egerton University; 2010. 27-30 p. Doi: 10.1111/j.1745-4565.2010.00284.x

8. Lazuardi M, Hermanto B, Restiadi TI. Assessment of the withdrawal period for ractopamine hydrochloride in the goat and sheep. Iraqi J Vet Sci. 2020;34(2):405-410. Doi: 10.33899/ijvs.2019.126114.1237

9. Dubois M, Fluchard D, Sior E, Delahaut PH. Identification and quantification of five macrolide antibiotics in several tissues, eggs and milk by liquid chromatography-electrospray tandem mass spectrometry. J Chromatography. 2001;753:189-202. Doi: 10.1016/S0378-4347(00)00542-9

10. Toldra F, Reig M. Methods for rapid detection of chemical and veterinary drug residues in animal foods. Tren Food Sci Technol. 2006;17(9):482-9. Doi: 10.1016/j.tifs.2006.02.002

11. Abdullah OA, Shareef AM, Sheet OH. Detection of streptomycin residues in local meat of bovine and ovine. Iraqi $\mathrm{J}$ Vet Sci. 2012;26(1):43-6. Doi: 10.33899/ijvs.2012.46958

12. Yousif SA, Jwher DhM. Detection of streptomycin residues in sheep carcasses in Duhok province, Kurdistan region. Iraq J Appl Vet Sci. 2019;4(2):41-44. Doi: 10.21608/JAVS.2019.62654.

13. Yousif SA. Use of ELISA for detection of some antibiotic residues in sheep carcasses at Duhok Abattoir [Master's thesis]. Duhok: Faculty of Veterinary Medicine, Duhok University; 2014. 50-57 p.

14. Beyene T. Veterinary drug residues in food-animal products: Its risk factors and potential effects on public health. J Vet Sci Technol. 2016;7:1-7. Doi: $10.4172 / 2157-7579.1000285$

15. Ahangaran MG, Peimani N, Dastgerdi AA. The effect of thyme (Thymus daenensis) supplement on growth and hygienic parameters of broilers meat. Iraqi J Vet Sci. 2019;33(1):87- 92. Doi: 10.33899/ijvs.2019.125526.1048

16. Al-Mashhadany DA. Monitoring of antibiotic residues among sheep meat in Erbil city and thermal processing effect on their remnants. Iraqi J Vet Sci. 2020;34(2):217-222. Doi: 10.33899/ijvs.2019.125814.1161

17. Li JH, Yousif MH, Li ZQ, Wu ZH, Li SL, Yang HJ, Wang YJ, Cao ZJ. Effects of antibiotic residues in milk on growth, ruminal fermentation, and microbial community of preweaning dairy calves. J Dairy Sci. 2019;102:2298-307. Doi: 10.3168/jds.2018-15506

18. Polidori P, Ortenzi A, Vincenzetti S, Beghelli D. Dietary properties of lamb meat and human health. Mediterr J Nutr Metab. 2011;(4):53-56. Doi: $10.1007 / \mathrm{s} 12349-010-0032-9$

19. Al-Dabbagh AS. Detection of the occurrence of antibiotic residues in different kinds of milk. Rafidain J Sci. 2012;23(3):83-92. Doi: $\underline{10.33899 / \text { rjs.2012.59625 }}$
20. Ibrahim AI, Junaidu AU, Garba MK. Multiple antibiotic residues in meat from slaughtered cattle in Nigeria. Internet $\mathrm{J}$ Vet Med. 2010;8(1):1-5. Doi: $10.5580 / 1 \mathrm{fcd}$

21. Hussein AEY, Elmansoury YH, Hussien MO, Taha MI, Mahgoub HA, El Hussein AM. Oxytetracycline residues in Sheep meat in Khartoum State, Sudan. J Adv Vet Anim Res. 2015;2(3):321-325. Doi: 10.5455/javar.2015.b101

22. Olatoye I, Ehinmowo A. Oxytetracycline residues in edible tissues of cattle slaughtered in Akure, Nigeria. Nigerian Vet J. 2011;31(2):1-9. Doi: $10.4314 /$ nvj.v31i2.68952

23. Gebre BA. Qualitative screening of antibiotic residues and identification of antibiotic resistant salmonella from raw and ready to eat meat in Thailand. Intl J Adv Life Sci. 2012;5(1):51-64.

24. Nonga HE, Mariki M, Karimuribo ED, Mdegela RH. Assessment of antimicrobial usage and antimicrobial residues in broiler chickens in Morogoro mnicipality, Tanzania. Pak J Nut Sci Alert. 2009;8(3):203207. Doi: $10.3923 /$ pjn. 2009.203.207

25. Abasi MM, Rashidi MR, Javadi A, Amirkhiz MB, Mirmahdavi S, Zabihi M. Levels of tetracycline residues in cattle meat, liver, and kidney from a slaughterhouse in Tabriz, Iran. Turk J Vet Anim Sci. 2009;33(4):345-349. Doi: 10.3906/vet-0711-32

26. Abbasi MM, Babaei H, Ansarin M. Simultaneous determination of tetracyclines residues in bovine milk samples by solid phase extraction and HPLC-FL method. Adva Pharm Bull. 2011;1(1):34. Doi:10.5681/apb.2011.005

27. Santos L, Rosa J, Freitas A, Leston S, Barbosa J, Ramos F. Detection and quantification of 47 antibiotic residues in farmed European sea bass (Dicentrarchus labrax) using a multi-class and multi-residue UHPLCMS/MS method. Food Addit Contam. 2019;4:561-570. Doi: 10.1080/19440049.2019.1572229

28. Babapour A, Azami L, Fartashmehr J. Overview of antibiotic residues in beef and mutton in Ardebil, north west of Iran. World Appl Sci J. 2012;19(10):1417-22. Doi: 10.5829/idosi.wasj.2012.19.10.1802

29. Er B, Onurdag FK, Demirhan B, Ozgacar SO, Oktem AB, Abbasoglu $\mathrm{U}$. Screening of quinolone antibiotic residues in chicken meat and beef sold in the markets of Ankara, Turkey. Poult Sci. 2013;92(8):2212-5. Doi: $10.3382 / \mathrm{ps} .2013-03072$

30. Akinwumi AO, Olatoye IO, Odunsi AA, Omojola AB, Rafiu TA. Effects of antibiotic residue on the physical qualities of beef in Oyo State, Nigeria. Agricul Anim Sci. 2012;47:73-76p. Doi: 10.015CAAS2012-T10025

31. Hakem A, Titouche Y, Houali K, Yabrir B, Malki O, Chenouf N, Yahiaoui S, Labiad M, Ghenim H, Kechin-Bounar S, Chirila F. Screening of antibiotics residues in poultry meat by microbiological methods. Vet Med. 2013;70(1):77-82. Doi: 10.15835/buasvmenvm:70:1:9832

32. Ortelli D, Spörri AS, Edder P. veterinary drug residue in food of animal origin in Switzerland: a health concern?. CHIMIA Int J Chem. 2018;72:713-717. Doi: 10.2533/chimia.2018.713

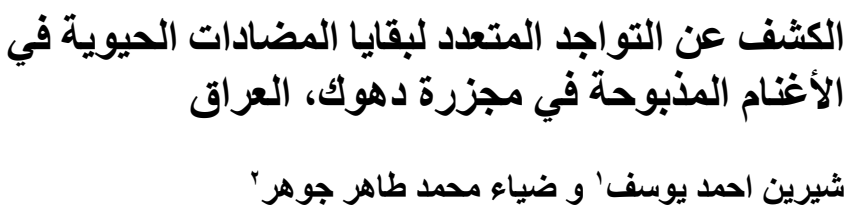

$$
\begin{aligned}
& \text { 'دائرة البيطرة في محافظة دهوك، ׳فرع الصحة العامة البيطرية، كلية }
\end{aligned}
$$

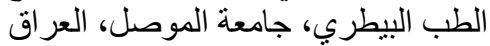

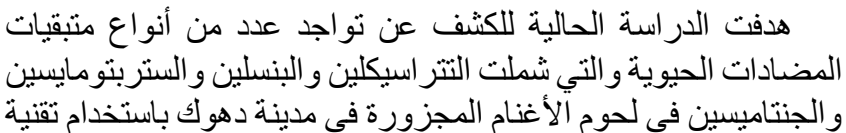


المضادات الحيوية على الأقل في العينات المفحوصة فضلا عن الوجود

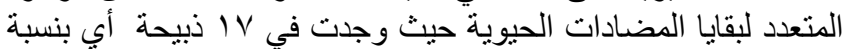

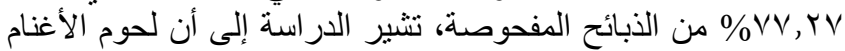

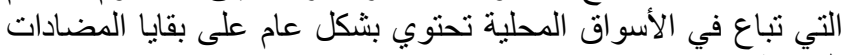

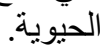

الالبز ا، حيث جمعت ثمان وثمانون عينة من مو اقع مختلفة من ب ب ذبيحة

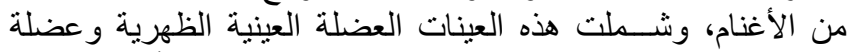

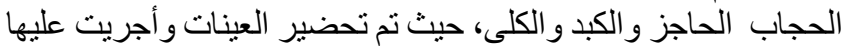

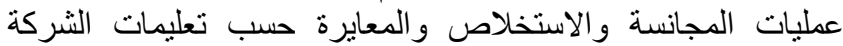
المصنعة لتقنية الفحص. أظهرت النتائج وجود نوع والنه واحد من بقايا 